\title{
Declining Utilization of Percutaneous Epidural Adhesiolysis in Medicare Population: Evidence-Based or Over-Regulated?
}

\author{
Laxmaiah Manchikanti, MD¹, Vidyasagar Pampati, MSc ${ }^{1}$, Ramsin M. Benyamin, MD $^{2}$, and \\ Joshua A. Hirsch, MD ${ }^{3}$
}

Background: Recent reviews have shown a reversal of growth of utilization of a majority of interventional techniques in the Medicare population post passage of the Affordable Care Act (ACA). Despite the presence of supportive evidence, there has been a significant decline in the utilization of percutaneous adhesiolysis. We hypothesize that this is most likely attributable to regulations governing interventional procedures and coverage policies.

Study Design: Assessment of utilization characteristics of percutaneous adhesiolysis procedures in managing chronic low back and lower extremity pain in fee-for-service (FFS) Medicare population.

Objective: To assess the utilization patterns of percutaneous adhesiolysis and correlation between regulations and declining utilization patterns.

Methods: FFS Medicare data from Centers for Medicare and Medicaid Services (CMS) Physician/Supplier Procedure Summary Master File from 2000 to 2016 was utilized.
Results: From 2009 to 2016, there was a decline of $53.2 \%$ with an annual decline of $10.3 \%$, whereas from 2000 to 2009, overall increase was $62.6 \%$ with an annual increase of $6.5 \%$ per 100,000 Medicare population. The states controlled by Noridian Medicare carrier have shown a steep decline of $100 \%$ from 2009 to 2016 due to a noncoverage policy issued by Noridian.

Limitations: This analysis has not included Medicare Advantage Plans. However, an overwhelming majority of Medicare Advantage Plans do not cover adhesiolysis procedures.

Conclusion: Percutaneous adhesiolysis procedures faced a steep decline in utilization from 2009 to 2016 of $53.2 \%$ and an annual decline of $10.3 \%$ per 100,000 Medicare population. This is occurring simultaneous to an increase in the evidence base.

Key words: Interventional techniques, chronic low back pain, lower extremity pain, epidural injections, percutaneous adhesiolysis, post-surgery syndrome, spinal stenosis, neuroplasty
Percutaneous epidural adhesiolysis is a minimally invasive therapeutic modality used in the treatment of patients with chronic low back and lower extremity pain, nonresponsive to conservative modalities of management, as well as fluoroscopically directed epi-

From : ${ }^{1}$ Pain Management Center of Paducah, Paducah, KY; ${ }^{2}$ Millennium Pain Center, Bloomington, IL, and University of Illinois, UrbanaChampaign, IL; ${ }^{3}$ Massachusetts General Hospital and Harvard Medical School, Boston, MA

Author for correspondence: Laxmaiah Manchikanti, MD

Address: Pain Management Center of Paducah, 2831 Lone Oak Rd, Paducah, Kentucky 42003

E-mail:drlm@thepainmd.com dural injections $(1,2)$. The evolution of this technology dates back to the 1980s by Racz (3) with placement of a reinforced catheter, followed by percutaneous adhesiolysis and targeted placement of a catheter with injection of multiple anti-inflammatory solutions. Extensive literature of this technology has been published with randomized controlled trials (RCTs) (4-8), systematic reviews $(1,2)$, and guidelines (9). Further, cost utility analysis of percutaneous adhesiolysis (10) was performed with favorable outcomes similar to epidural injections $(11,12)$ with cost utility of $\$ 4,426$ per one year of quality-adjusted life year (QALY) with one-day percutaneous adhesiolysis, with repeat procedures performed in post lumbar surgery syn- 
drome and spinal stenosis. Manchikanti et al (13), in an assessment of utilization characteristics, showed utilization of the adhesiolysis procedures to be 22 per 100,000 Medicare fee-for-service (FFS) population increasing to 33 by 2011, with a $47 \%$ total increase and an annual geometric increase of $3.6 \%$.

A recent publication of utilization patterns of interventional techniques has shown a reversal of growth patterns following passage of the Affordable Care Act (ACA) (14). This analysis from 2000 to 2016 showed that epidural and adhesiolysis procedures had experienced significant declines in the utilization patterns overall of $11.6 \%$ and $1.7 \%$ per annum for 100,000 Medicare population from 2009 to 2016 . This followed similar patterns of previous analysis (14-18).

Favorable evidence from RCTs and systematic reviews continues to accumulate for percutaneous adhesiolysis $(1,2-9)$. Noridian has instituted a noncoverage policy leading to denial of the procedure by Medicare Advantage plans and multiple other insurers (19). In addition, the lack of local coverage determinations (LCDs) by many other carriers also has led Medicare Advantage plans to deny the service (20). Further, the overall health care milieu has changed with numerous regulations related to practice management affecting utilization of various procedures (21-35). Despite the changes, the United States' (US) spending on personal health care continues to rise with reduced access, without change in quality, despite opinions from proponents of these regulations (19-38).

Consequently, we hypothesized that the issue of noncoverage policy and negative publicity in the payor community continues to contribute to the decline in utilization of these percutaneous adhesiolysis procedures. This assessment is undertaken to describe utilization characteristics and assess the relationship between noncoverage policy and utilization in FFS Medicare population from 2000 to 2016.

\section{METHODS}

The utilization of percutaneous adhesiolysis was performed utilizing Strengthening the Reporting of Observational Studies in Epidemiology (STROBE) guidance (39). Due to the nature of public data, approval by the Institutional Review Board (IRB) was not required. The data was nonattributable to individuals and is available through the Centers for Medicare and Medicaid Services (CMS) database (40).

\section{STUDY DESIGN}

The study was designed to assess utilization patterns of percutaneous adhesiolysis procedures in the FFS Medicare population in the US from 2000 to 2016 .

\section{Participants}

Participants included the FFS Medicare recipients from 2000 to 2016.

For this analysis, the current procedure codes for percutaneous adhesiolysis (CPT 62264 and 62263) were utilized and allowed services were calculated. The data is calculated for overall services for each technique, and rate of services for 100,000 Medicare beneficiaries.

\section{Data Compilation}

The data was compiled using Microsoft Access 2010 and Microsoft Excel 2010 (Microsoft, Redmond, WA).

\section{RESULTS}

\section{Utilization Characteristics}

Table 1 shows the utilization patterns of percutaneous adhesiolysis procedures from 2009 to 2016 declined $53.2 \%$, at an annual decline of $10.3 \%$ per 100,000 Medicare population. An overall decrease of $23.8 \%$ from 2000 to 2016 was with an annual decline of $1.7 \%$. Further analysis showed that from 2000 to 2009, there was an increase in utilization patterns of $62.6 \%$ per 100,000 Medicare population with an annual increase of $6.5 \%$. Table 1 also shows adhesiolysis procedures per 100,000 to peak in 2005 from 22 per 100,000 population in 2000 to 43 in 2005, and decline to 17 per 100,000 population with gradual decline over the years with a $95.5 \%$ decline from 2005 to 2016.

Figure 1 shows the frequency of utilization of 3-day and 1-day adhesiolysis procedures in Medicare population, with significant decline and disappearance of a 3-day procedure with an overall decline of all percutaneous adhesiolysis procedures.

\section{Statewide Utilization Data}

Table 2 shows the rate of utilization of percutaneous adhesiolysis procedures from 2009 to 2016 based on Medicare Administrative Contractors. Noridian, the largest carrier with a penchant for noncoverage policies, has shown the greatest decline $(100 \%)$ for 
Declining Utilization of Percutaneous Epidural Adhesiolysis in Medicare Population

Table 1. Utilization of 3-day and 1-day adhesiolysis procedures in the Medicare population from 2000 to 2016.

\begin{tabular}{|c|c|c|c|c|c|c|c|c|c|}
\hline \multirow[b]{2}{*}{ Year } & \multicolumn{3}{|c|}{62263 3-day Adhesiolysis Procedures } & \multicolumn{3}{|c|}{ 62264* 1-day Adhesiolysis Procedures } & \multicolumn{3}{|c|}{ Adhesiolysis Procedures } \\
\hline & Services & Rate & PCPY & Services & Rate & PCPY & Services & Rate & PCPY \\
\hline 2,000 & 8,778 & 22 & NA & - & - & NA & 8,778 & 22 & \\
\hline 2,001 & 10,463 & 26 & $18.0 \%$ & 503 & 1 & NA & 10,966 & 27 & $23.6 \%$ \\
\hline 2,002 & 14,430 & 36 & $36.4 \%$ & 724 & 2 & NA & 15,154 & 37 & $36.6 \%$ \\
\hline 2,003 & 7,183 & 17 & $-51.0 \%$ & 9,733 & 24 & NA & 16,916 & 41 & $9.9 \%$ \\
\hline 2,004 & 2,628 & 6 & $-63.9 \%$ & 14,152 & 34 & $43.3 \%$ & 16,780 & 40 & $-2.2 \%$ \\
\hline 2,005 & 2,972 & 7 & $11.0 \%$ & 15,392 & 36 & $6.8 \%$ & 18,364 & 43 & $7.5 \%$ \\
\hline 2,006 & 2,146 & 5 & $-29.2 \%$ & 15,757 & 36 & $0.4 \%$ & 17,903 & 41 & $-4.4 \%$ \\
\hline 2,007 & 1,553 & 4 & $-29.1 \%$ & 15,781 & 36 & $-1.9 \%$ & 17,334 & 39 & $-5.2 \%$ \\
\hline 2,008 & 1,269 & 3 & $-20.4 \%$ & 15,499 & 34 & $-4.3 \%$ & 16,768 & 37 & $-5.7 \%$ \\
\hline 2,009 & 1,199 & 3 & $-6.3 \%$ & 15,294 & 33 & $-2.2 \%$ & 16,493 & 36 & $-2.5 \%$ \\
\hline 2,010 & 1,023 & 2 & $-16.7 \%$ & 14,527 & 31 & $-7.3 \%$ & 15,550 & 33 & $-8.0 \%$ \\
\hline 2,011 & 948 & 2 & $-10.0 \%$ & 14,374 & 30 & $-3.9 \%$ & 15,322 & 32 & $-4.3 \%$ \\
\hline 2,012 & 939 & 2 & $-4.9 \%$ & 13,521 & 27 & $-9.7 \%$ & 14,460 & 29 & $-9.4 \%$ \\
\hline 2,013 & 646 & 1 & $-33.3 \%$ & 13,144 & 25 & $-5.8 \%$ & 13,790 & 27 & $-7.6 \%$ \\
\hline 2,014 & 514 & 1 & $-22.8 \%$ & 12,282 & 23 & $-9.4 \%$ & 12,796 & 24 & $-10.0 \%$ \\
\hline 2,015 & 363 & 1 & $-31.2 \%$ & 10,221 & 19 & $-18.9 \%$ & 10,584 & 19 & $-19.4 \%$ \\
\hline 2,016 & 414 & 1 & $10.8 \%$ & 9,116 & 16 & $-13.3 \%$ & 9,530 & 17 & $-12.5 \%$ \\
\hline \multicolumn{10}{|c|}{ Percentage of change from 2000 to 2016} \\
\hline Change & $-95.3 \%$ & $-96.7 \%$ & & $-6.3 \%$ & $-31.8 \%$ & & $8.6 \%$ & $-23.8 \%$ & \\
\hline GM & $-17.4 \%$ & $-19.2 \%$ & & $-0.5 \%$ & $-2.9 \%$ & & $0.5 \%$ & $-1.7 \%$ & \\
\hline \multicolumn{10}{|c|}{ Percentage of change from 2000 to 2009} \\
\hline Change & $-86.3 \%$ & $-88.2 \%$ & & $57.1 \%$ & $41.1 \%$ & & $87.9 \%$ & $62.6 \%$ & \\
\hline GM & $-17.5 \%$ & $-18.5 \%$ & & $8.4 \%$ & $7.1 \%$ & & $7.3 \%$ & $6.5 \%$ & \\
\hline \multicolumn{10}{|c|}{ Percentage of change from 2009 to 2016} \\
\hline Change & $-65.5 \%$ & $-72.0 \%$ & & $-40.4 \%$ & $-51.7 \%$ & & $-42.2 \%$ & $-53.2 \%$ & \\
\hline GM & $-14.1 \%$ & $-16.6 \%$ & & $-7.1 \%$ & $-9.9 \%$ & & $-7.5 \%$ & $-10.3 \%$ & \\
\hline
\end{tabular}

Rate- Per 100,000 population

GM- Geometric average annual change

PCPY- Percentage of change from previous year

* - for 62264 Change \& GM are from 2003 to 2016 and from 2003 to 2009

all states from 2009 to 2016 , versus an annual decline was $100 \%$ per 100,000 Medicare population. All the states except Missouri and Maryland have shown significant decreases.

\section{DISCUSSION}

The present assessment of utilization data of percutaneous adhesiolysis procedures in managing chronic low back and lower extremity pain in Medicare FFS population from 2000 to 2016 showed dramatic shifts with $53.2 \%$ or $10.3 \%$ annual rate of decline from 2009 to 2016 after enactment of ACA compared to 2000 to
2009 pre-ACA, which showed an increase of $62.6 \%$ or an annual increase of $6.5 \%$. The dramatic changes have been attributed to the philosophical approach of ACA and other regulations $(12,41,42)$, which increased the insurance, but at the same time reduced the coverage overall. This was also aided by multiple other factors such as LCDs with no coverage or no LCDs at all (19), reduced reimbursement $(25,26)$, and an inappropriate analysis of evidence-base $(12,41,42)$. The declines have been noted in spite of significant RCTs and systematic reviews publication $(1,2,4-9)$. Further, cost utility analysis also showed 


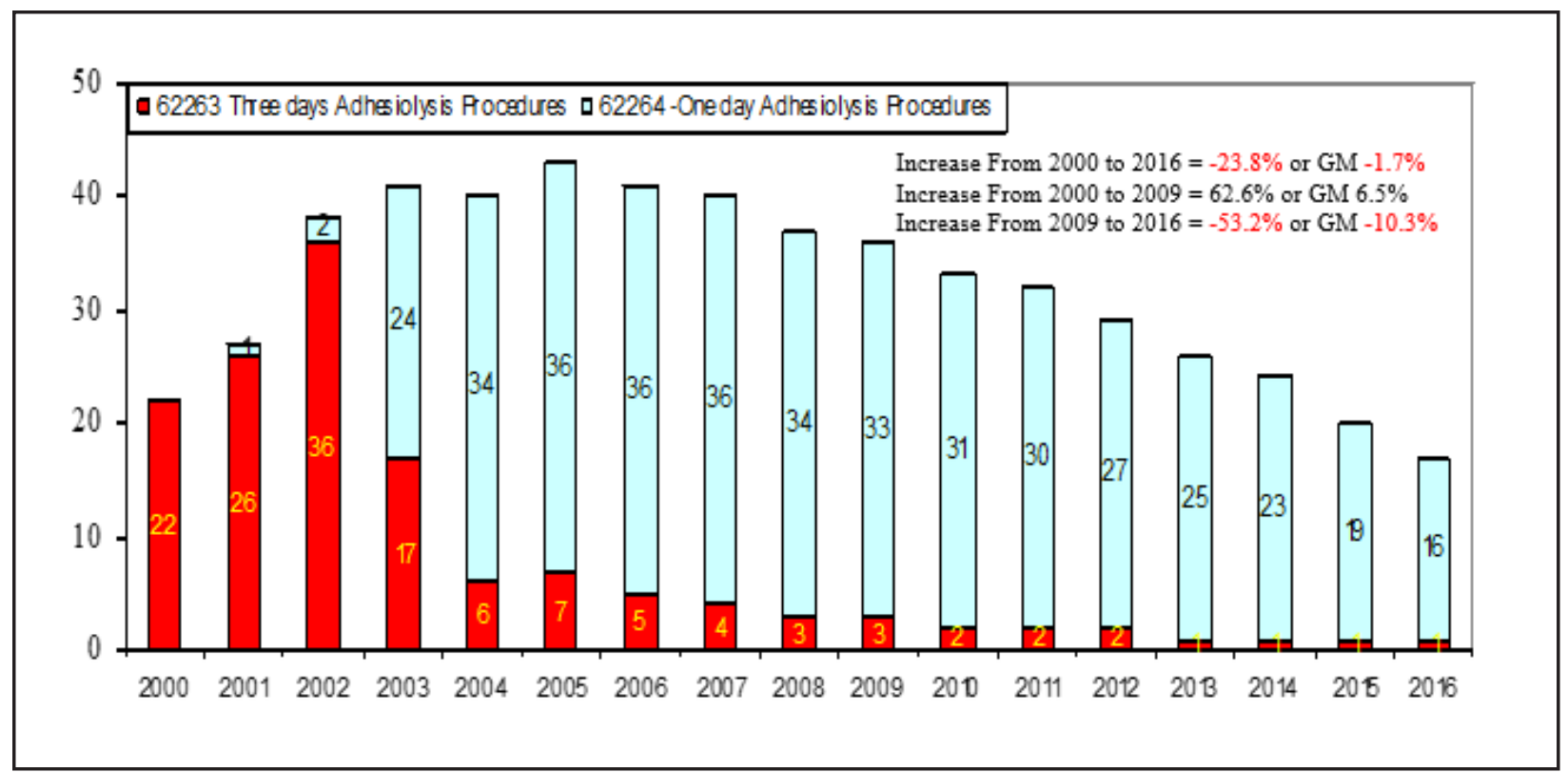

Fig 1. Frequency of utilization of 3-day and 1-day adhesiolysis procedures from 2000 to 2016, in Medicare recipients.

favorable outcomes at $\$ 4,426$ for one- year of QALY compared to multiple other interventions, including spinal cord stimulation and surgical interventions, similar to epidural injections in patients with chronic recalcitrant pain after failure of various modalities of treatments and surgical intervention in the majority of cases $(10,11,43-47)$.

The ACA, also known as Obamacare, along with many other regulations relating to the practice of medicine, was implemented with 3 primary goals; increasing the number of insured, improving the quality of care, and controlling health care costs (21-35). However, the regulations have increased practice management costs, shifted practices to the hospital-based, and significantly impacted independent practices; reducing access (18). US spending on personal health care and public health continues to rise with annual health care costs of $\$ 3.3$ trillion for 2016 (36-38). In addition, Dieleman et al $(37,38)$ in publications describing US spending on personal health care and public health, showed expenditures of $\$ 183.5$ billion in managing musculoskeletal disorders, including low back and neck pain. Further, they argued that most of the increases were related to price increases, whereas CMS data showed that aging was one of the major factors. During the same time, pain and disability continued to escalate, along with opioid usage and opioid-related deaths $(48,49)$. Even then, officials continue to make efforts to reduce utilization and reduce the reimbursement rates $(25,26,35,50-55)$.

The claims of lack of increase in chronic spinal pain continue to be exaggerated (56-60). As Dieleman et al $(37,38)$ have shown, overall spending on back and neck pain has substantially increased at a more rapid pace than many other conditions. Additionally, surgical interventions related to spinal pain with micro discectomies, open discectomies, decompression, and complex fusions continues to increase (61-63). Increasing disability secondary to low back pain has been described in conjunction with reports of increasing prevalence $(50,58-60)$. Further, the increasing diagnosis of prevalence and appreciation of disability and increasing utilization of multiple different modalities, contributes to understanding the structural basis of chronic low back and lower extremity pain. This facilitates the development of technologies based on the principles of accountable and value-based interventional pain management $(50,61-65)$. In actuality, the evidence for percutaneous adhesiolysis is better than many other modalities of treatments offered for low back and lower extremity pain, including surgical interventions in managing low back pain of post-surgery syndrome and spinal stenosis, with 
Declining Utilization of Percutaneous Epidural Adhesiolysis in Medicare Population

Table 2. Rate of utilization of adhesiolysis procedures from 2009 to 2016, in FFS Medicare recipients by 2016 Medicare Administrative Contractors.

\begin{tabular}{|c|c|c|c|c|c|c|c|c|c|c|c|}
\hline \multirow[b]{2}{*}{ Carrier } & \multirow[b]{2}{*}{ State } & \multicolumn{8}{|c|}{ Rate Per 100,000 Medicare Beneficiaries Population } & \multirow[b]{2}{*}{ Change } & \multirow[b]{2}{*}{ GM } \\
\hline & & 2009 & 2010 & 2011 & 2012 & 2013 & 2014 & 2015 & 2016 & & \\
\hline \multirow[t]{4}{*}{ Cahaba } & Alabama & 312.8 & 304.8 & 281.4 & 267.4 & 250.1 & 233.4 & 219.4 & 227.0 & $-27 \%$ & $-4.5 \%$ \\
\hline & Georgia & 14.1 & 9.1 & 6.3 & 5.2 & 9.1 & 7.3 & 9.4 & 7.4 & $-48 \%$ & $-8.8 \%$ \\
\hline & Tennessee & 4.1 & 5.9 & 5.2 & 4.4 & 2.2 & 2.4 & 1.7 & 1.6 & $-60 \%$ & $-12.3 \%$ \\
\hline & Total & 91.7 & 87.6 & 79.5 & 74.8 & 70.5 & 65.0 & 61.7 & 62.6 & $-32 \%$ & $-5.3 \%$ \\
\hline \multirow[t]{3}{*}{ CGS } & Kentucky & 68.9 & 68.2 & 69.8 & 55.3 & 43.0 & 30.7 & 29.9 & 24.0 & $-65 \%$ & $-14.0 \%$ \\
\hline & Ohio & 37.6 & 26.6 & 29.7 & 18.9 & 16.3 & 11.7 & 12.8 & 9.6 & $-75 \%$ & $-17.8 \%$ \\
\hline & Total & 46.5 & 38.5 & 41.2 & 29.4 & 24.0 & 17.2 & 17.7 & 13.7 & $-71 \%$ & $-16.0 \%$ \\
\hline First Coast & Florida & 54.1 & 45.2 & 51.7 & 55.4 & 55.2 & 44.2 & 33.7 & 33.7 & $-38 \%$ & $-6.5 \%$ \\
\hline \multirow[t]{11}{*}{ NGS } & Connecticut & 8.4 & 9.9 & 9.2 & 8.4 & 4.5 & 5.1 & 9.8 & 10.2 & $21 \%$ & $2.7 \%$ \\
\hline & Illinois & 24.6 & 25.2 & 24.0 & 18.9 & 15.4 & 13.6 & 15.3 & 8.9 & $-64 \%$ & $-13.6 \%$ \\
\hline & Maine & 16.6 & 9.8 & 8.5 & 6.9 & 6.7 & 10.3 & 4.0 & 4.2 & $-74 \%$ & $-17.7 \%$ \\
\hline & Massachusetts & 13.5 & 8.7 & 11.6 & 9.8 & 10.2 & 12.4 & 18.2 & 17.7 & $31 \%$ & $3.9 \%$ \\
\hline & Minnesota & 1.3 & 0.4 & 0.6 & 1.5 & 1.8 & 0.9 & 0.2 & 0.1 & $-92 \%$ & $-29.8 \%$ \\
\hline & New Hampshire & 6.0 & 5.8 & 3.1 & 1.3 & 0.0 & 0.0 & 0.4 & 1.5 & $-75 \%$ & $-17.9 \%$ \\
\hline & New York & 31.4 & 22.4 & 21.1 & 16.6 & 17.6 & 19.2 & 20.1 & 17.9 & $-43 \%$ & $-7.7 \%$ \\
\hline & Rhode Island & 0.0 & 2.2 & 2.2 & 4.8 & 3.3 & 0.0 & 1.1 & 0.0 & & \\
\hline & Vermont & 7.4 & 9.0 & 2.6 & 1.7 & 0.0 & 0.0 & 0.0 & 0.0 & $-100 \%$ & $-100.0 \%$ \\
\hline & Wisconsin & 9.1 & 7.2 & 5.6 & 3.8 & 7.8 & 9.4 & 6.3 & 6.4 & $-30 \%$ & $-4.9 \%$ \\
\hline & Total & 19.5 & 15.7 & 15.0 & 12.0 & 11.7 & 12.3 & 13.3 & 11.3 & $-42 \%$ & $-7.5 \%$ \\
\hline \multirow[t]{13}{*}{ Noridian } & Alaska & 0.0 & 1.5 & 0.0 & 4.3 & 0.0 & 10.8 & 0.0 & 21.0 & & \\
\hline & Arizona & 20.6 & 15.4 & 19.2 & 8.2 & 0.0 & 0.0 & 0.0 & 0.0 & $-100 \%$ & $-100.0 \%$ \\
\hline & California & 50.1 & 61.4 & 62.9 & 62.9 & 60.9 & 43.4 & 11.1 & 0.0 & $-100 \%$ & $-100.0 \%$ \\
\hline & Idaho & 3.6 & 0.9 & 2.5 & 0.0 & 0.0 & 0.0 & 0.0 & 0.0 & $-100 \%$ & $-100.0 \%$ \\
\hline & Montana & 2.4 & 5.3 & 4.6 & 2.8 & 0.0 & 0.0 & 0.0 & 0.0 & $-100 \%$ & $-100.0 \%$ \\
\hline & Nevada & 6.4 & 1.4 & 2.2 & 2.6 & 3.3 & 2.0 & 0.5 & 0.0 & $-100 \%$ & $-100.0 \%$ \\
\hline & North Dakota & 0.0 & 0.0 & 0.0 & 0.9 & 0.0 & 0.0 & 0.0 & 0.0 & & \\
\hline & Oregon & 0.3 & 0.5 & 0.5 & 0.9 & 0.0 & 0.0 & 0.0 & 0.0 & $-100 \%$ & $-100.0 \%$ \\
\hline & South Dakota & 9.7 & 7.3 & 1.4 & 5.0 & 0.0 & 0.0 & 0.0 & 0.0 & $-100 \%$ & $-100.0 \%$ \\
\hline & Utah & 1.8 & 0.7 & 0.3 & 0.3 & 0.0 & 0.0 & 0.0 & 0.0 & $-100 \%$ & $-100.0 \%$ \\
\hline & Washington & 6.4 & 3.4 & 3.5 & 3.4 & 0.1 & 0.0 & 0.0 & 0.0 & $-100 \%$ & $-100.0 \%$ \\
\hline & Wyoming & 1.3 & 0.0 & 0.0 & 0.0 & 0.0 & 0.0 & 0.0 & 0.0 & $-100 \%$ & $-100.0 \%$ \\
\hline & Total & 31.0 & 35.9 & 37.1 & 35.9 & 32.7 & 22.7 & 6.0 & 1.1 & $-96 \%$ & $-37.6 \%$ \\
\hline \multirow[t]{9}{*}{ Novitas } & Arkansas & 6.3 & 7.5 & 5.9 & 7.1 & 8.5 & 0.0 & 6.7 & 0.0 & $-100 \%$ & $-100.0 \%$ \\
\hline & Colorado & 0.3 & 0.8 & 0.8 & 1.0 & 0.3 & 0.3 & 1.1 & 0.1 & $-62 \%$ & $-12.8 \%$ \\
\hline & $\mathrm{DC}$ & 91.3 & 78.1 & 15.0 & 7.4 & 8.4 & 4.1 & 5.4 & 1.1 & $-99 \%$ & $-46.6 \%$ \\
\hline & Delaware & 1.4 & 0.0 & 0.0 & 0.0 & 0.0 & 0.0 & 0.6 & 0.0 & $-100 \%$ & $-100.0 \%$ \\
\hline & Louisiana & 21.9 & 19.1 & 11.5 & 23.4 & 13.1 & 10.0 & 10.9 & 16.0 & $-27 \%$ & $-4.4 \%$ \\
\hline & Maryland & 4.6 & 3.7 & 2.2 & 3.5 & 2.7 & 2.2 & 2.3 & 6.6 & $43 \%$ & $5.3 \%$ \\
\hline & Mississippi & 17.0 & 7.2 & 6.9 & 5.2 & 16.0 & 23.3 & 14.8 & 9.1 & $-46 \%$ & $-8.5 \%$ \\
\hline & New Jersey & 38.8 & 43.0 & 19.8 & 9.6 & 11.8 & 10.4 & 11.4 & 13.1 & $-66 \%$ & $-14.3 \%$ \\
\hline & New Mexico & 10.2 & 2.2 & 2.5 & 4.8 & 4.8 & 1.7 & 1.1 & 1.3 & $-87 \%$ & $-25.2 \%$ \\
\hline
\end{tabular}


Table 2 (cont.). Rate of utilization of adhesiolysis procedures from 2009 to 2016, in FFS Medicare recipients by 2016 Medicare Administrative Contractors.

\begin{tabular}{|l|c|c|c|c|c|c|c|c|c|c|c|}
\hline & & \multicolumn{7}{|c|}{ Rate Per 100,000 Medicare Beneficiaries Population } & \multicolumn{2}{l|}{} \\
\hline Carrier & State & $\mathbf{2 0 0 9}$ & $\mathbf{2 0 1 0}$ & $\mathbf{2 0 1 1}$ & $\mathbf{2 0 1 2}$ & $\mathbf{2 0 1 3}$ & $\mathbf{2 0 1 4}$ & $\mathbf{2 0 1 5}$ & $\mathbf{2 0 1 6}$ & Change & GM \\
\hline & Oklahoma & 25.7 & 21.7 & 24.1 & 23.3 & 20.3 & 20.8 & 36.8 & 38.3 & $49 \%$ & $5.9 \%$ \\
\hline & Pennsylvania & 5.1 & 7.6 & 6.6 & 3.3 & 4.2 & 2.1 & 5.5 & 4.5 & $-12 \%$ & $-1.8 \%$ \\
\hline & Texas & 108.6 & 89.9 & 88.2 & 80.7 & 71.6 & 77.9 & 66.2 & 52.1 & $-52 \%$ & $-10.0 \%$ \\
\hline & Total & 40.7 & 35.7 & 31.4 & 28.3 & 26.2 & 27.1 & 25.5 & 21.5 & $-47 \%$ & $-8.7 \%$ \\
\hline $\begin{array}{l}\text { Palmetto } \\
\text { GBA }\end{array}$ & North Carolina & 15.3 & 12.8 & 15.7 & 14.8 & 11.0 & 7.5 & 3.6 & 5.3 & $-66 \%$ & $-14.1 \%$ \\
\hline & South Carolina & 9.8 & 7.9 & 7.6 & 9.9 & 6.8 & 10.7 & 8.3 & 6.7 & $-31 \%$ & $-5.2 \%$ \\
\hline & Virginia & 8.6 & 12.0 & 11.1 & 7.5 & 5.0 & 7.7 & 7.5 & 8.4 & $-2 \%$ & $-0.3 \%$ \\
\hline & West Virginia & 3.4 & 3.4 & 6.5 & 3.8 & 2.3 & 0.7 & 1.9 & 0.7 & $-79 \%$ & $-20.0 \%$ \\
\hline & Total & 10.9 & 10.6 & 11.7 & 10.5 & 7.5 & 7.6 & 5.6 & 6.1 & $-44 \%$ & $-8.0 \%$ \\
\hline WPS & Indiana & 13.9 & 9.1 & 8.4 & 5.1 & 5.7 & 4.4 & 5.1 & 1.8 & $-87 \%$ & $-25.2 \%$ \\
\hline & Iowa & 0.6 & 0.8 & 1.0 & 0.2 & 2.4 & 0.7 & 0.7 & 0.3 & $-40 \%$ & $-7.1 \%$ \\
\hline & Kansas & 45.8 & 26.8 & 13.2 & 27.9 & 33.7 & 20.5 & 18.4 & 17.7 & $-61 \%$ & $-12.7 \%$ \\
\hline & Michigan & 68.5 & 66.0 & 53.0 & 47.2 & 42.7 & 42.4 & 39.2 & 31.5 & $-54 \%$ & $-10.5 \%$ \\
\hline & Missouri & 6.7 & 5.1 & 5.6 & 7.3 & 15.3 & 30.5 & 27.1 & 33.5 & $401 \%$ & $25.9 \%$ \\
\hline & Nebraska & 8.7 & 1.1 & 1.1 & 9.4 & 2.4 & 0.3 & 2.0 & 0.6 & $-93 \%$ & $-31.2 \%$ \\
\hline & Total & 31.9 & 27.7 & 22.2 & 21.6 & 22.3 & 23.6 & 21.8 & 19.6 & $-39 \%$ & $-6.7 \%$ \\
\hline
\end{tabular}

$\mathrm{GM}=$ Geometric average annual change

evidence also supporting the administration of the procedure in recalcitrant nonresponsive chronic disc herniation $(2,8)$. Helm et al $(2)$ in a systematic review of percutaneous adhesiolysis reviewed, 7 RCTs and 3 observational studies, meeting inclusion criteria. They provided strong or Level I evidence of the efficacy of percutaneous adhesiolysis in the treatment of chronic refractory low back and lower extremity pain. Other systematic reviews also provided similar evidence.

The LCDs for coverage of percutaneous adhesiolysis are very few with one noncoverage policy (Noridian) $(13,64,65)$. Further, Medicare Advantage plans continue to issue noncoverage based on the absence of LCDs. Thus, it is crucial that an appropriate LCD is prepared for percutaneous adhesiolysis based on the Program Integrity Manual (66) meeting reasonable and necessary provisions. This manual along with revisions in the Cures Act clearly provide the instructions for utilization of published authoritative evidence derived from RCTs or other definitive studies. In addition, cost effectiveness has been illustrated for percutaneous adhesiolysis, along with multiple interventional techniques, in recent years utilizing the approach utilized for well-regarded cost utility analysis of surgical procedures $(10,11,43-47)$. Based on this analysis, the cost utility of percutaneous adhesiolysis was calculated as direct costs and total costs extrapolated with $40 \%$ allocated for indirect costs. The cost of percutaneous adhesiolysis for one-year quality of improvement has been estimated as $\$ 4,426$, higher than caudal epidural injection of $\$ 3,628$, interlaminar epidural injections of $\$ 3,301$, but similar to therapeutic medial branch blocks in managing chronic neck pain or low back pain of $\$ 4,261$ or $\$ 3,715.85(10,11,43$ 47). These reports favorably compared to overall cost effectiveness of disc herniation surgery of $\$ 69,403$ per QALY, spinal stenosis, cost of $\$ 77,600$ per QALY, and cost of $\$ 115,600$ per QALY for degenerative spondylolisthesis $(46,47)$.

Limitations of this assessment include that this review is restricted to only Medicare FFS population in the US with lack of inclusion of patients from Medicare Advantages plan. Bearing that in mind, given coverage decisions associated with Medicare Advantage, we believe that including this data would demonstrate even more significant reductions in or absence of utilization.

In summary, the noncoverage policy by Noridian influencing other insurers in declining to issue LCDs has resulted in diminution of percutaneous adheolysis 
Declining Utilization of Percutaneous Epidural Adhesiolysis in Medicare Population

procedures. We believe that this has been detrimental to patient care. In addition, the reductions in payment by Medicare has also contributed to declining utilization.

\section{CONCLUSION}

From 2009 to 2016 , percutaneous adhesiolysis pro- cedures decreased substantially at a $53.8 \%$ overall per 100,000 population with an annual decrease of $10.3 \%$ due to ACA, multiple regulations, and inappropriate assessment of the literature leading to flawed conclusions and biases.

\section{REFERENCES}

1. Manchikanti L, Manchikanti KN, Gharibo CG, Kaye AD. Efficacy of percutaneous adhesiolysis in the treatment of lumbar post surgery syndrome. Anesth Pain Med 2016; 6:e26172.

2. Helm S 2nd, Racz GB, Gerdesmeyer L, Justiz R, Hayek SM, Kaplan ED, El Terany MA, Knezevic NN. Percutaneous and endoscopic adhesiolysis in managing low back and lower extremity pain: A systematic review and meta-analysis. Pain Physician 2016; 19:E245-E282.

3. Racz GB, Sabonghy M, Gintautas J, Kline WM. Intractable pain therapy using a new epidural catheter. JAMA 1982; 248:579581.

4. Heavner JE, Racz GB, Raj P. Percutaneous epidural neuroplasty. Prospective evaluation of $0.9 \% \mathrm{NaCl}$ versus $10 \% \mathrm{NaCl}$ with or without hyaluronidase. Reg Anesth Pain Med 1999; 24:202207.

5. Manchikanti L, Singh V, Cash KA, Pampati V, Datta S. Assessment of effectiveness of percutaneous adhesiolysis and caudal epidural injections in managing lumbar post surgery syndrome: A 2-year follow-up of randomized, controlled trial. J Pain Res 2012; 5:597-608.

6. Manchikanti L, Cash KA, McManus CD, Pampati V. Assessment of effectiveness of percutaneous adhesiolysis in managing chronic low back pain secondary to lumbar central spinal canal stenosis. Int J Med Sci 2013; 10:50-59.

7. Gerdesmeyer L, Wagenpfeil S, Birkenmaier C, Veihelmann A, Hauschild M, Wagner K, Muderis MA, Gollwitzer H, Diehl P, Toepfer A. Percutaneous epidural lysis of adhesions in chronic lumbar radicular pain: A randomized, double-blind, placebocontrolled trial. Pain Physician 2013; 16:185-196.

8. Veihelmann A, Devens C, Trouillier H, Birkenmaier C, Gerdesmeyer L, Refior HJ. Epidural neuroplasty versus physiotherapy to relieve pain in patients with sciatica: A prospective randomized blinded clinical trial. J Orthop Sci 2006; 11:365-369.

9. Manchikanti L, Abdi S, Atluri S, Benyamin RM, Boswell MV, Buenaventura RM, Bryce DA, Burks PA, Caraway DL, Calodney AK, Cash KA, Christo PJ, Cohen SP, Colson J, Conn A, Cordner H, Coubarous S, Datta S, Deer TR, Diwan S, Falco FJ, Fellows B, Geffert S, Grider JS, Gupta S, Hameed H, Hameed M, Hansen $H$, Helm S 2nd, Janata JW, Justiz R, Kaye AD, Lee M, Manchikanti KN, McManus CD, Onyewu O, Parr AT, Patel VB, Racz GB, Sehgal N, Sharma ML, Simopoulos TT, Singh V, Smith HS, Snook LT, Swicegood JR, Vallejo R, Ward SP, Wargo BW, Zhu J, Hirsch JA. An update of comprehensive evidence-based guidelines for interventional techniques in chronic spinal pain. Part II: Guidance and recommendations. Pain Physician 2013; 16:S49S283.

10. Manchikanti L, Helm S 2nd, Pampati V, Racz GB. Cost utility analysis of percutaneous adhesiolysis in managing pain of postlumbar surgery syndrome and lumbar central spinal stenosis.

Pain Pract 2015; 15:414-422.

11. Manchikanti L, Falco FJE, Pampati V, Cash KA, Benyamin RM, Hirsch JA. Cost utility analysis of caudal epidural injections in the treatment of lumbar disc herniation, axial or discogenic low back pain, central spinal stenosis, and post lumbar surgery syndrome. Pain Physician 2013; 16:E129-E143.

12. Manchikanti L, Knezevic NN, Boswell MV, Kaye AD, Hirsch JA. Epidural injections for lumbar radiculopathy and spinal stenosis: A comparative systematic review and meta-analysis. Pain Physician 2016; 19:E365-E410.

13. Manchikanti L, Helm II S, Pampati V, Racz GB. Percutaneous adhesiolysis procedures in the medicare population: Analysis of utilization and growth patterns from 2000 to 2011. Pain Physician 2014; 17:E129-E139.

14. Manchikanti L, Soin A, Mann DP, Bakshi S, Pampati V, Hirsch $J A$. Reversal of growth of utilization of interventional techniques in managing chronic pain in Medicare population post Affordable Care Act. Pain Physician 2017; 20:551-567.

15. Manchikanti L, Pampati V, Falco FJE, Hirsch JA. An updated assessment of utilization of interventional pain management techniques in the Medicare population: 2000 - 2013. Pain Physician 2015; 18:E115-E127.

16. Manchikanti L, Pampati V, Hirsch JA. Utilization of interventional techniques in managing chronic pain in Medicare population from 2000 to 2014: An analysis of patterns of utilization. Pain Physician 2016; 19:E531-E546.

17. Manchikanti L, Hirsch JA, Pampati V, Boswell MV. Utilization of facet joint and sacroiliac joint interventions in Medicare population from 2000 to 2014: Explosive growth continues! Curr Pain Headache Rep 2016; 20:58.

18. Manchikanti L, Pampati V, Hirsch JA. A retrospective cohort study of utilization patterns of epidural injections for spinal pain in the U.S. fee-for-service Medicare population from 2000 to 2014. BMJ Open 2016; 6:E013042.

19. Noridian Healthcare Solutions, LLC. Local Coverage Determination (LCD). Non Covered Services (L36219). Effective Date: 10/1/2015.

20. American Society of Interventional Pain Physicians. Fact Sheet. Fact Sheet on Inappropriate Reimbursement Patterns of Medicare Advantage Plans.

21. Manchikanti L, Helm S 2nd, Benyamin RM, Hirsch JA. A critical analysis of Obamacare: Affordable care or insurance for many and coverage for few? Pain Physician 2017; 20:111-138.

22. Manchikanti L, Hirsch JA. Repeal and replace of Affordable Care: A complex, but not an impossible task. Pain Physician 2016; 19:E1109-E1113.

23. Bauchner $\mathrm{H}$, Fontanarosa $\mathrm{PB}$. The future of US health care policy. JAMA 2016; 315:1339-1340. 
24. Obama B. United States health care reform: Progress to date and next steps. JAMA 2016; 316:525-532.

25. Manchikanti L, Kaye AD, Hirsch JA. Proposed Medicare physician payment schedule for 2017: Impact on interventional pain management practices. Pain Physician 2016; 19:E935-E955.

26. Manchikanti L, Singh V, Hirsch JA. Facility payments for interventional pain management procedures: Impact of proposed rules. Pain Physician 2016; 19:E957-E984.

27. Hirsch JA, Nicola G, McGinty G, Liu RW, Barr RM, Chittle MD, Manchikanti L. ICD-10: History and context. AJNR Am J Neuroradiol 2016; 37:596-599.

28. Manchikanti L, Hammer M, Benyamin RM, Hirsch JA. Physician Quality Reporting System (PQRS) for interventional pain management practices: Challenges and opportunities. Pain Physician 2016; 19:E15-E32.

29. Hirsch JA, Harvey HB, Barr RM, Donovan WD, Duszak R Jr Nicola GN, Schaefer PW, Manchikanti L. Sustainable growth rate repealed, MACRA revealed: Historical context and analysis of recent changes in Medicare physician payment methodologies. AJNR Am J Neuroradiol 2016; 37:210-214.

30. Hirsch JA, Leslie-Mazwi TM, Barr RM, McGinty G, Nicola GN, Patel AB, Manchikanti L. The Burwell roadmap. ] Neurointerv Surg 2016; 8:544-546.

31. Schuster MA, Onorato SE, Meltzer DO. Measuring the cost of quality measurement: A missing link in quality strategy. JAMA 2017; 318:1219-1220

32. Hirsch JA, Leslie-Mazwi TM, Nicola GN, Bhargavan-Chatfield M, Seidenwurm DJ, Silva E, Manchikanti L. PQRS and the MACRA: Value-based payments have moved from concept to reality. AJNR Am J Neuroradiol 2016; 37:2195-2200.

33. Manchikanti L, Helm S 2nd, Benyamin RM, Hirsch JA. MeritBased Incentive Payment System (MIPS): Harsh choices for interventional pain management physicians. Pain Physician 2016; 19:E917-E934.

34. Hirsch JA, Leslie-Mazwi TM, Patel AB, Rabinov JD, Gonzalez RG, Barr RM, Nicola GN, Klucznik RP, Prestigiacomo CJ, Manchikanti L. MACRA: Background, opportunities and challenges for the neurointerventional specialist. ] Neurointerv Surg 2016; 8:868-874

35. Hirsch JA, Leslie-Mazwi TM, Barr RM, McGinty G, Nicola GN, Silva E 3rd, Manchikanti L. The bundled payments for care improvement initiative. J Neurointerv Surg 2016; 8:547-548.

36. Hartman $M$, Martin AB, Espinosa N, Catlin A, The National Health Expenditure Accounts Team. National Health Care Spending In 2016: Spending And Enrollment Growth Slow After Initial Coverage Expansions. Health Aff (Millwood) 2017 Dec 6. [Epub ahead of print]

37. Dieleman JL, Baral R, Birger M, Bui AL, Bulchis A, Chapin A, Hamavid H, Horst C, Johnson EK, Joseph J, Lavado R, Lomsadze L, Reynolds A, Squires E, Campbell M, DeCenso B, Dicker D, Flaxman AD, Gabert R, Highfill T, Naghavi M, Nightingale $\mathrm{N}$, Templin T, Tobias MI, Vos T, Murray CJ. US spending on personal health care and public health, 1996-2013. JAMA 2016; 316:2627-2646.

38. Dieleman JL, Squires E, Bui AL, Campbell M, Chapin A, Hamavid H, Horst C, Li Z, Matyasz T, Reynolds A, Sadat N, Schneider MT, Murray CJL. Factors associated with increase in US health care spending, 1996-2013. JAMA 2017; 318:1668-1678.

39. Vandenbroucke JP, Von Elm E, Altman DG, et al; Iniciativa STROBE. Strengthening the reporting of observational studies in epidemiology (STROBE): Explanation and elaboration. Gac Sanit 2009; 23:158.

40. Specialty Utilization data files from Centers for Medicare and
Medicaid Services. www.cms.hhs.gov/ (Accessed March 22, 2016).

41. Chou R, Hashimoto R, Friedly J, Fu R, Dana T, Sullivan S, Bougatsos C, Jarvik J. Pain Management Injection Therapies for Low Back Pain. Technology Assessment Report ESIB0813. (Prepared by the Pacific Northwest Evidence-based Practice Center under Contract No. HHSA 290-2012-00014-I.) Rockville, MD: Agency for Healthcare Research and Quality; July 10, 2015.

www.cms.gov/medicare/coverage/determinationprocess/downloads/ id98ta.pdf

42. Boswell MV, Manchikanti L. Appropriate design and methodologic quality assessment, clinically relevant outcomes are essential to determine the role of epidural corticosteroid injections. Commentary RE: Chou R, Hashimoto R, Friedly J, Fu R, Bougatsos C, Dana T, Sullivan SD, Jarvik J. Epidural corticosteroid injections for radiculopathy and spinal stenosis: A systematic review and meta-analysis. Ann Intern Med 2015; 163:373-381. Evid Based Med 2016; 21:89.

43. Manchikanti L, Pampati V, Benyamin RM, Hirsch JA. Cost utility analysis of lumbar interlaminar epidural injections in the treatment of lumbar disc herniation, central spinal stenosis, and axial or discogenic low back pain. Pain Physician 2017; 20:219-228.

44. Manchikanti L, Pampati V, Kaye AD, Hirsch JA. Cost utility analysis of cervical therapeutic medial branch blocks in managing chronic neck pain. Int J Med Sci 2017; 14:1307-1316.

45. Manchikanti L, Pampati V, Kaye AD, Hirsch JA. Therapeutic lumbar facet joint nerve blocks in the treatment of chronic low back pain: Cost analysis based on a randomized controlled trial. Korean J Med 2018; in press.

46. Tosteson AN, Skinner JS, Tosteson TD, Lurie JD, Andersson Gb, Berven S, Grove MR, Hanscom B, Blood EA, Weinstein JN. The cost effectiveness of surgical versus nonoperative treatment for lumbar disc herniation over two years: Evidence from the Spine Patient Outcomes Research Trial (SPORT). Spine (Phila Pa 1976) 2008; 33:2108-2115.

47. Tosteson AN, Lurie JD, Tosteson TD, Skinner JS, Herkowitz $\mathrm{H}$, Albert T, Boden SD, Bridwell K, Longley M, Andersson GB, Blood EA, Grove MR, Weinsten JN; SPORT Investigators. Surgical treatment of spinal stenosis with and without degenerative spondylolisthesis: Cost-effectiveness after 2 years. Ann Intern Med 2008; 149:845-53.

48. Manchikanti L, Kaye AM, Knezevic NN, McAnally H, Trescot AM, Blank S, Pampati V, Abdi S, Grider JS, Kaye AD, Manchikanti KN, Cordner HJ, Gharibo CG, Harned ME, Albers SL, Atluri S, Aydin SM, Bakshi S, Barkin R, Benyamin RM, Boswell MV, Buenaventura RM, Calodney AK, Cedeno DL, Datta $S$, Deer TR, Fellows B, Galan V, Grami V, Hansen H, Helm S 2nd, Justiz R, Koyyalagunta D, Malla Y, Navani A, Nouri K, Pasupuleti R, Sehgal N, Silverman SM, Simopoulos TT, Singh V, Slavin KV, Solanki DR, Staats PS, Vallejo R, Wargo BW, Watanabe A, Hirsch JA. Responsible, safe, and effective prescription of opioids for chronic non-cancer pain: American Society of Interventional Pain Physicians (ASIPP) guidelines. Pain Physician 2017: 20:2S:S3-S92.

49. Katz J. The first count of fentanyl deaths in 2016: Up 540\% in three years. New York Times, September 2, 2017.

50. Social Security Administration. Annual Statistical Report on the Social Security Disability Insurance Program, 2011. Baltimore, MD, Office of Research Evaluation and Statistics, 2011.

www.ssa.gov/policy/docs/statcomps/di_asr/2011/di_asr11.pdf

51. Manchikanti L, Pampati V, Benyamin RM, Hirsch JA. Cost calculation methodology exacerbates site-of-services differential by 10- to 18-fold for soft tissue and joint injections in hospital out- 
Declining Utilization of Percutaneous Epidural Adhesiolysis in Medicare Population

patient departments. IPM Reports 2017; 1:183-189

52. Hirsch JA, Leslie-Mazwi TM, Nicola GN, Barr RM, Bello JA, Donovan WD, Tu R, Alson MD, Manchikanti L. Current procedural terminology: A primer. J Neurolntervent Surg 2015; 7:309312.

53. Hirsch JA, Silva E 3rd, Nicola GN, Barr RM, Bello JA, Manchikanti L, Donovan WD. The RUC: A primer for neurointerventionalists. J Neurointerv Surg 2014; 6:61-64.

54. Hirsch JA, Donovan WD, Leslie-Mazwi TM, Nicola GN, Manchikanti L, Silva E 3rd. Component coding and the neurointerventionalist: A tale with an end. ] Neurointerv Surg 2013; 5:615619.

55. Donovan WD, Leslie-Mazwi TM, Silva E 3rd, Woo HH, Nicola GN, Barr RM, Bello JA, Tu R, Hirsch JA. Diagnostic carotid and cerebral angiography: A historical summary of the evolving changes in coding and reimbursement in a complex procedure family. J Neurointerv Surg 2014; 6:712-717.

56. Freburger JK, Holmes GM, Agans RP, Jackman AM, Darter JD, Wallace AS, Castel LD, Kalsbeek WD, Carey TS. The rising prevalence of chronic low back pain. Arch Intern Med 2009; 169:251-258.

57. Bressler HB, Keyes WJ, Rochon PA, Badley E. The prevalence of low back pain in the elderly. A systemic review of the literature. Spine (Phila Pa 1976) 1999; 24:1813-1819.

58. Hoy D, Brooks P, Blyth F, Buchbinder R. The epidemiology of low back pain. Best Pract Res Clin Rheumatol 2010; 24:769-781.

59. Hoy DG, Bain C, Williams G, March L, Brooks P, Blyth F, Woolf
A, Vos T, Buchbinder R. A systematic review of the global prevalence of low back pain. Arthritis Rheum 2012; 64:2028-2037.

60. Buchbinder R, Blyth FM, March LM, Brooks P, Woolf AD, Hoy DG. Placing the global burden of low back pain in context. Best Pract Res Clin Rheumatol 2013; 27:575-589.

61. Rajaee SS, Bae HW, Kanim LE, Delamarter RB. Spinal fusion in the United States: Analysis of trends from 1998 to 2008. Spine (Phila Pa 1976) 2012; 37:67-76.

62. Bae HW, Rajaee SS, Kanim LE. Nationwide trends in the surgical management of lumbar spinal stenosis. Spine (Phila Pa 1976) 2013; 38:916-926.

63. Deyo RA, Mirza SK, Martin BI, Kreuter W, Goodman DC, Jarvik JG. Trends, major medical complications, and charges associated with surgery for lumbar spinal stenosis in older adults. JAMA 2010; 303:1259-1265.

64. Manchikanti L, Helm II S, Singh V, Hirsch JA. Accountable interventional pain management: A collaboration among practitioners, patients, payers, and government. Pain Physician 2013; 16:E635-E670.

65. Manchikanti L, Falco FJE, Benyamin RM, Helm II S, Singh V, Hirsch JA. Value-based interventional pain management: A review of Medicare national and local coverage determination policies. Pain Physician 2013; 16:E145-E180.

66. Medicare Program Integrity Manual. Publication \# 100-08.

www.cms.gov/Regulations-and-Guidance/Guidance/Manuals/Internet-Only-Manuals-IOMs-Items/CMS019033.html (Accessed August 27, 2013)

IPM Reports Vol. 2, No. 1, 2018 
